\title{
KEMANDIRIAN DAN MOTIVASI BELAJAR BIOLOGI SISWA MENGGUNAKAN GOOGLE CLASSROOM PADA MASA PANDEMI COVID-19
}

\author{
Rikizaputra $^{1)}$, Al Khudri Sembiring ${ }^{2)}$, Marta Dinata ${ }^{3)}$, Minda Azhar ${ }^{4)}$, Yohandri ${ }^{5)}$ \\ ${ }^{1,2,3}$ Jurusan Pendidikan Biologi, Universitas Lancang Kuning \\ ${ }^{4,5}$ Jurusan Pendidikan IPA, Universitas Negeri Padang \\ Email $^{1)}$ :rikizaputra@unilak.ac.id \\ Email $^{2}$ :alkhudri_s@unilak.ac.id \\ Email $^{3)}$ :martadinata@unilak.ac.id
}

\begin{abstract}
ABSTRAK: Kemandirian dan motivasi belajar siswa melalui google classroom menjadi penting dalam situasi pandemi Covid-19. Tujuan penelitian ini adalah untuk menganalisis dampak google classroom terhadap kemandirian dan motivasi belajar siswa pada masa pandemi covid-19. Penelitian ini merupakan penelitian kuantitatif dengan metode survey. Populasi dalam penelitian ini berjumlah 52 siswa dengan sampel penelitian 52 siswa yang diambil dengan menggunakan teknik total sempling. Teknik pengumpulan data menggunakan kuesioner yang terdiri dari 30 pernyataan dengan skala likert dan wawancara terhadap siswa. Berdasarkan analisis data yang dilakukan dengan deskriptif perentase yang mengacu pada skala likert 1-4 maka diperoleh rata-rata kemandirian belajar 2,19 dan rerata motivasi belajar siswa diperoleh 2,46. Dengan demikian dapat disimpulkan bahwa pengunaan google classroom dalam pembelajaran pada masa pendemi covid 19 memberikan dampak yang sedang terhadap kemandirian dan berdampak kuat terhadap motivasi. Penggunaan google classroom pada masa pandemi covid-19 perlu ditingkatkan kualitas penggunannya dalam pembelajaran.
\end{abstract}

Kata kunci: Kemandirian, motivasi, google classroom, pandemi covid-19

ABSTRACT: The independence and motivation of students to learn through Google Classroom is important in the Covid-19 pandemic situation. The purpose of this study was to analyze the impact of google classroom on students' independence and learning motivation during the covid-19 pandemic. This research is a quantitative research with survey method. The population in this study amounted to 52 students with a research sample of 52 students who were taken using the total sampling technique. The data collection technique used a questionnaire consisting of 30 statements with a Likert scale and interviews with students. Based on data analysis conducted by descriptive percentage which refers to a Likert scale of 1-4, the average learning independence is 2.19 and the average student motivation is 2.46. Thus, it can be concluded that the use of google classroom in learning during the covid 19 pandemic has a moderate impact on independence and has a strong impact on motivation. The use of google classroom during the covid-19 pandemic needs to be improved in terms of the quality of its use in learning.

Keywords: The Independence, motivation, google classroom, covid-19 pandemic

\section{PENDAHULUAN}

Pembelajaran merupakan perubahan perubahan perilaku sebagai hasil interaksi antara dirinya dan lingkungannya dalam memenuhi kebutuhan hidupnya. Hamalik (2010), menyatakan bahwa pembelajaran diartikan sebagai suatu proses yang dilakukan oleh individu untuk memperoleh perubahan perilaku yang baru secara keseluruhan, sebagai hasil dari pengalaman individu itu sendiri dalam interaksi dengan lingkungannya".
Pembelajaran tersebut seharusnya berlangsung secara interaksi dua arah memalui metode yang melibatkan siswa secara aktif yang dapat menciptakan pembelajaran bermakna. Keberlangsunan proses pembelajaran dipenagruhi oleh berbagai kondisi dan situasi.

Sejak akhir tahun 2019, dunia dilanda oleh wabah Covid 19. Hal ini merubah situasi dan kondisi setiap sektor kehidupan termasuk pada bidang pendidikan. Sebagaimana Khasanah (2020) menyatakan bahwa Covid 19 
sudah merubah berbagai sektor. Purwanto et al (2020) menambahkan bahwa pendidikan merupakan bidang yang juga menerima dampak signifikan. Manusia dipaksa untuk mengambil langkah-langkah cepat untuk mengatasi situasi yang ada.

Negara negara di dunia umumnya menutup lembaga pendidikan seperti sekolah, perguruan tinggi, tempat bimbingan belajar dan lain sebagainya. Kondisi seperti ini juga terjadi di Indonesia. Langkah ini diambil dalam rangka mencegah dan menhentikan penularan covid 19. Lembaga pendidikan dianggap sebagai salah satu tempat potensial terjadinya penularan virus, karena ditempat ini dipastikan terjadi banyak interaksi langsung antara manusia, sementara covid 19 dapat menular jika tejadi kontak langsung ataupun tidak langsung antara indiviu yang terjangkit dengan yang tidak terkonfirmasi positif.

Kondisi sperti ini tidak mungkin dibiarkan begitu saja dalam waktu yang lama, mengingat sektor pendidikan merupakan sektor penting yang harus dijaga keberlangsungannya, karena pendidikan mencetak generasi bangsa yang akan menentukan arah bangsa ini kedepan melalui berbagai proses pembelajaran yang terjadi di dalamnya. Oleh sebab itu, pemerintah Indonesia mengambil langkah solutif agar proses pembelajaran disekolah tetap berjalan, yaitu dengan merubah pola pembelajaran dari tatap muka menjadi pembelajaran online. Firman dan Rahayu (2020) menyatakan bahwa salah satu langkah pemerintah untuk menjamin tetap berlangsungnya proses pembelajaran adalah dengan mengarahkan agar pembelajaran yang selama ini berlagsung secara tatap muka dirubah dengan pembelajaran secara daring artinya materi materi pembelajaran disampaikan kepada siswa melalui media internet, agar tidak terjadi penumpukan manusia pada titik titik tertentu sehingga dapat memutus rantai penularan virus.

Sampai hari ini pembelajaran daring tetap harus menjadi pilihan dalam proses pendidikan, sehingga guru dan siswa harus menggunakan berbagai platform yang ada yang dimungkinkan untuk berlansungnya proses pembelajaran, seperti whatsup, zoom meeting, google classroom, google meet dan lain sebagainya. Dari survey awal yang dilakukan peneliti, di SMAN 1 Roak IV Koto secara umum guru dan siswa lebih memilih untuk menggunakan platform google classrom, karena dianggap lebih praktis digunakan dan tersedia berbagai menu yang diperlukan dalam pembelajaran serta lebih ekonomis.

Kehadiran media pembelajaran berbasis teknologi pada masa panemi ini sanagat diperlukan, selain itu guru juga dituntut harus mampu menggunakan berbagai media tersebut secara efektif dan efisien agar pesan pembelajaran tetap secara efektif dapat tersampaikan (Pujilestari, 2020). Pemahaman guru dalam mengunakan media berbasis teknologi akan mempengaruhi proses transformasi materi kepada siswa terutama pada materi atau mata pelajaran mata pelajaran yang bersifat abstrak.

Biologi merupakan mata pelajaran wajib di sekolah yang di dalamnya terkandung konsep-konsep yang bersifat abstrak, artinya konsep konsep yang tidak bisa diamanti dengan kasat mata, tetapi perlu metode atau cara tersenditi dalam memahaminya. Masruroh et al (2014) menyatakan bahwa biologi banyak dijumpai dilingkungan sekitar, tetapi tidak semua berwujud konkrit, banyak konsepkonsep biologi yang bersifat abstrak. Pada konsep-konsep yang abstrak siswa banyak yang mengalmi kesulitan. Sehingga perlu cara yang tepat untuk melatih kemandirian siswa dalam belajar agar materi yang mereka pelajari lebih bermakna serta merangsang semanagt siswa dalam memahami konsep-konsep tersebut.

Pembelajaran berbasis google classroom pada masa pandemi ini lebih menitikberatkan kepada siswa untuk belajar secara aktif dan mandiri dengan berbagai tugas yang diberikan oleh guru. Artinya, pembelajaran seperti ini membutuhkan kemandirian belajar siswa agar substransi dari berbagai materi yang disajikan oleh guru melalui media berbasis teknologi ini bisa dipahami oleh siswa. Bungsu et al (2019) menyatakan, kemandirian belajar harus menjadi hal penting yang diperhatikan pada masa pembelajaran pandemi ini, karena kemandirian belajar yang tertanam dengan baik di dalam diri siswa akan melatihdan menjadikan siswa lebih 
bertanggungjawab dengan tugas dan target pembelajaran yang diberikan . Fajriah et al (2019), kemandirian belajar mempengaruhi hasil belajar siswa, kemandirian yang baik akan menunjukkan hasil belajar yang baik, dan begitu juga sebaliknya.

Kemandirian artinya sikap yang tidak ketergantungan dengan orang lain, dalam kontek pembelajaran kemadirian siswa dapat dilihat dari kesungguhan dalam menjalankan tanggungjawab dan memiliki inisiatif dalam menyelesakan masalah (Suhendri, 2015). Olehsebab itu, menurut Ningsih dan Nurohman (2016), kemandirian menjadi sikap dasar yang harus dimiliki oleh seseorang agar mampu hidup mandiri dan memiliki inisitaif dalam mengerjakan dan menyesaikan berbagai tugas yang ada.

Dalam proses pembelajaran, kemandirian tidak bisa dipisahkan dari motivasi belajar. Untuk bekerja secara mandiri perlu didorong oleh motivasi. Semakin tinggi motivasi maka siswa akan semakin rajin dalam mengerjakan berbagai tugas secara mandiri. Murti et al (2019) menemukan bahwa semakin sering siwa melakukan aktivitasnya sevcara sendiri maka menunjukkan motivasi yang lebih baik.

Motivasi merupakan faktor penting yang harus ada dan selalu dijaka dalam diri siswa, apalagi pada situasi pembelajaran pada masa pandemi covid 19 ini, siswa jarang bertemu dan bertatap muka dengan guru, aktivitas pembelajaran banyak dilakukan secara daring, kondisi ini jika tidak disiasati dengan pengunaan media yang variatif, dikuatirkan akanmengurangi motvasi siswa dalam belajar (Basuki, 2015). Sementara itu, Lestari (2017) menemukan bahwa motivasi mempegaruhi hasil belajar. Karena menurut Cleopatra (2015), motivasi adalah energi yang mendorong seseorang melakukan sesutu.

Motivasi ada dua aspek, yaitu aspek intrinsik dan ekstrinsik. Motivasi intrinsik merupakan motivasi yang bersumber dari dalam diri seseorang, ini meruakan energi iternal yang mendorong seseorang melakukan sesuatu, sehingga motivasi intrinsik yang baik melahirkan tekat dan inisiatif yang kuat dalam diri seseorang. Sementara, motivasi ekstrinsik merupakan motivasi yang bersumber dari faktor luar diri seseorang, artinya motivasi ini sangat dipengaruhi oleh lingkungan. Dalam konteks pembelajaran, sapek ekstrinsik ini dapat meliputi guru, orang tua, teman, sarana pembelajaran. Jika lingkungan baik maka motivasi siswa juga akan baik (Lomu dan Widodo, 2018).

Pada kondisi lingkungan saat ini, ditengah pembelajaran pada masa pandemi Covid 19 ini, motivasi pembelajaran harus selalu dikembangkan, walaupun tidak tatap muka dangan siswa, tetapi tentunya peningkatan moivasi melalui peningkatan interaksi melalui dunia maya. Kurniawan \& Wustqa (2014), menyatakan motivasi perlu dikembangkan dalam pembelajaan karena melalui motivasi bealajar siswa terdorong untuk giat dalam belajar.

Kemandirian dan motivasi akan melatih siswa untuk mampu melakukan evaluasi sendiri terhadap kegiatan yang dilakukannya (Jumaisyaroh et al., 2015). Berdasarkan latarbelakang yang dipaparkan, maka perlu dilakukan penelitian tentang gambaran kemandirian dan motivasi belajar siswa sebagai dampak dari pembelajaran online berbasis google classroom yang dilakukan guru di SMAN 1 Rokan IV Koto selama masa pandemi Covid-19.

\section{METODE PENELITIAN}

Penelitian ini merupakan
penelitian survey menggunakan pendekatan kuantitatif dengan metode deskriptif. Dilaksanakan di SMAN 1 Rokan IV Koto kelas XII IPA semester ganjil Tahun Ajaran 2020/2021. Populasi dalam penelitian ini merupakan kelas XII IPA dengan sampel penelitian 52 siswa yang diambil dengan menggunakan teknik sampling. Instrumen yang digunakan sebagai pengumpulan data adalah angket kemandirian siswa yang digunakan terdiri dari 5 indikator dan angket motivasi siswa belajar yang digunakan terdiri dari 8 indikator, dengan mengacu pada scala likert 1-4. Lembar angket yang digunakan dalam penelitian ini berbentuk kuisioner yang dibuat dalam google form agar mudah diakses oleh siswa. Teknik analisis data dalam penelitian ini menggunakan deskriptif persentase 


\section{HASIL DAN PEMBAHASAN}

Data yang sudah dikumpulkan selanjutnya dianalisis. Ada dua variabel yang dianalisis dalam penelitian ini yakni kemandirian belajar dan motivasi belajar siswa. Untuk lebih jelas, hasil analisis tersebut disajikan sebagai berikut:

\section{Kemandirian Belajar Siswa}

Untuk mengetahui kemandirian belajar siswa secara komprehensif, dapat dilihat dari lima indikator, rerata kemandirian belajar siswa secara lengkap dapat dilohat pada tabel berikut: Tabel 1. Kemandirian Belajar Siswa

\begin{tabular}{|c|c|c|c|c|}
\hline No & Indikator & Skor & $(\%)$ & Kategori \\
\hline 1 & Bebas bertanggung & 2 & 57,4 & Sedang \\
\hline 2 & Progresif dan ulet & 2 & 62,6 & Tinggi \\
\hline 3 & Inisiatif atau kreatif & 2 & 62,8 & Tinggi \\
\hline 4 & Pengendalian diri & 2 & 52,0 & Sedang \\
\hline 5 & Kemampuan diri & 2 & 72,9 & Tinggi \\
\hline \multicolumn{2}{|c|}{ Rata-r } & 2 & 54,7 & Sedang \\
\hline
\end{tabular}

Pada Tabel 1 dapat diketahui rerata kemandirian belajar siswa tiap indikator dan secara keseluruhan. Berdasarkan indikator bebas bertanggung jawab 2,29 (57,45\%) dengan kategori sedang, progresis dan ulet 2,51 (62,64\%) dengan kategori tinggi, inisiatif atau kreatif 2,52 $(62,88 \%)$ dengan kategori tinggi, pengendalian diri 2,08 (52,08\%) dengan kategori sedang, dan kemampuan diri 2,92 (72,96\%) dengan kategori tinggi. Hal ini membuktikan bahwa kemandirian belajar siswa melalui google classroom termasuk dalam kategori tinggi dan sedang.

Tinggi rendahnya kemandirian belajar siswa dapat dipengaruhi karena kemampuan siswa dalam mengelola kemandirian yang ada pada diri mereka ketika mengikuti pembelajaran, sehingga saat mengikuti pembelajaran siswa tidak khawatir dan gelisah. Kemandirian siswa akan menuntut mereka untuk aktif baik sebelum dan sesudah proses pembelajaran berlangsung (Egok, 2016). Siswa yang mandiri akan mempersiapkan materi yang akan dipelajari, sehingga siswa yang menerapkan belajar mandiri akan mendapat prestasi lebih baik jika dibandingkan dengan siswa yang tidak menerapkan prinsip mandiri.

Berdasarkan hasil analisis kemandirian belajar siswa pada indikator bebas bertanggung jawab dengan skor rata-rata sebesar 2,29 dengan kategori sedang, hal ini menunjukkan bahwa siswa selalu menunda waktu dalam mengerjakan tugas di google classroom dan siswa selalu membuang-buang waktu sehingga tugas siswa menjadi menumpuk dan membuat siswa menjadi malas mengerjakannya. Menurut Susilowati (2009) Kemandirian belajar adalah kondisi aktifitas belajar yang mandiri, tidak tergantung dengan orang lain, memiliki kemauan serta tanggung jawab sendiri dalam menyelesaikan masalah belajarnya. Maka kemandirian belajar akan terwujud apabila siswa aktif mengontrol sendiri segala sesuatu yang akan dikerjakan, mengevaluasi dan selanjutnya merencanakan sesuatu yang lebih dalam pembelajaran yang dilalui dan siswa juga mau aktif dalam proses pembelajaran.Seseorang yang memiliki kemandirian belajar adalah mereka yang memiliki sifat percaya diri, inisiatif, disiplin dan tanggung jawab.

Berdasarkan hasil analisis kemandirian belajar siswa pada indikator progresif dan ulet dengan skor rata-rata sebesar 2,51 dengan kategori tinggi, hal ini menunjukkan bahwa siswa tidak mudah menyerah bila menghadapi masalah tekun dalam usaha mengejar prestasi, mempunyai usaha dalam mewujudkan harapannya, melakukan berbagai cara untuk mencapai tujuan dan menyukai hal-hal yang menantang (Kartadinata, 2001). Dangan itu siswa selalu ulet dalam menghadapi kesulitan dalam belajar melalui google classroom.

Berdasarkan hasil analisis kemandirian belajar siswa pada indikator inisiatif atau kreatif dengan skor rata-rata sebesar 2,52 dengan kategori tinggi, hal ini menunjukkan bahwa siswa mempunyai kreatifitas yang tinggi, mempunyai ide-ide yang cemerlang, menyukai hal-hal yang baru, suka mencoba-coba dan tidak suka meniru orang lain. Dangan itu siswa menjadi mandiri dan rajin membaca, dengan hal itu membuat pengetahuan siswa menjadi bertambah dengan belajar melalui google classroom. Siswa yang mempunyai kemandirian belajar dapat dilihat dari kegiatan belajarnya, dia tidak perlu disuruh bila belajar dan kegiatan belajar dilaksanakan atas inisiatif dirinya sendiri. Hal tersebut dikatakan bahwa faktor yang mempengaruhi tingginya 
kemandirian belajar siswa adalah harus memiliki kepercayaan diri terhadap kemampuan yang dimilikinya. Tindakan tersebut jelas sekali bukan mencerminkan seorang siswa yang memiliki kemandirian belajar padahal siswa harus mempunyai kemandirian yang tinggi yang harus dimilikinya.

Berdasarkan hasil analisis kemandirian belajar siswa pada indikator pengendalian diri dengan skor rata-rata sebesar 2,08 dengan kategori sedang, hal ini menunjukkan bahawa siswa kurang mampu mengendalikan emosi, mengendalikan tindakan, menyelesaian masalah secara damai, berpikir dulu sebelum bertindak, mendisiplinkan diri. Sehingga siswa kurang memahami materi, dan siswa selalu asal-asalan dalam menjawab pertanyaan sehingga membuat nilai siswa menjadi menurun. Menurut Tahar (2006) mengatakan pengendalian diri arat kaitannya dengan konsep diri, maka jika seseorang memiliki konsepdiri yang negatif terhadap dirinya, maka akan menyebabkan seseorang tersebut memiliki rasa tidak percaya terhadap dirinya sendiri.

Berdasarkan hasil analisis kemandirian belajar siswa pada indikator kemantapan diri dengan skor rata-rata sebesar 2,92 dengan kategori tinggi, hal ini menunjukkan bahwa siswa mengenal diri sendiri secara mendalam, dapat menerima diri sendiri, percaya pada kemampuan sendiri, memperoleh kepuasan dari usaha sendiri dan tidak mudah terpengaruh oleh orang lain (Kartadinata, 2001). Dengan ini siswa selalu berusaha sendiri dan selalu memperhatikan penyampaian yang disampaikan oleh guru sehingga membuat siswa lebih mandiri.

Berdasarkan hasil analisis kemandirian belajar siswa diketahui bahwa indikator yang memperoleh skor tertinggi yaitu indikator 5 tentang kemampuan diri, dengan skor 2,92 termasuk dalam kategori tinggi. Hal ini berarti ketika siswa mengikuti pembelajaran biologi melalui google classroom, mereka tidak mengalami gangguan seperti main games pada saat pembelajaran berlangsung di google classroom. Contohnya ketika ada tugas yang diberikan oleh guru maka siswa akan antusias mengerjakannya dan mencari sumber dari internet dan lebih mementingkan tugas dari pada main games sehingga siswa akan memperoleh kepuasan dari usaha sendiri dan tidah mudah terpengaruh dengan hal yang menganggu belajarnya. Dengan demikian apabila siswa mandirian dalam belajar siswa akan konsentrasi saat menghadapi ujian, hal ini akan mendapat pengaruh positif pada hasil belajar mereka.

Hasil penelitian menunjukkan bahwa siswa dengan kemandirian belajar yang baik cenderung belajar dengan baik dan dapat mengevaluasi apa yang dilakukannya (Jumaisyaroh, et al., 2015). Berdasarkan ilustrasi permasalahan tersebut maka melalui penelitian ini diharapkan siswa mampu meningkatkan kemandirian dan motivasinya, sehingga siswa tersebut dapat mencapai hasil belajar terbaik. Berdasarkan pendapat para pakar diatas dapat disimpulkan bahwa kemandirian belajar siswa sangat diperlukan dalam proses pembelajaran tanpa harus bergantung pada guru, sehingga proses belajar mengajar akan lebih optimal.

\section{Motivasi Belajar Siswa}

Untuk mengetahui motivasi siswa dalam belajar IPA secara komprehensif, dapat dilihat dari delapan indikator, rerata motivasi belajar siswa secara lengkap dapat dilihat pada tabel berikut:

Tabel 2. Motivasi Belajar Siswa

\begin{tabular}{|c|c|c|c|c|}
\hline No & Indikator & $\begin{array}{r}\text { Rerata } \\
\text { skor }\end{array}$ & $(\%)$ & Kategori \\
\hline 1 & $\begin{array}{l}\text { Hasrat dan keinginan } \\
\text { berhasil }\end{array}$ & 2,57 & 64,1 & Tinggi \\
\hline 2 & $\begin{array}{l}\text { Dorongan dan } \\
\text { kebutuhan dalam } \\
\text { belaiar }\end{array}$ & 2,50 & 62,5 & Tinggi \\
\hline 3 & $\begin{array}{l}\text { Adanya harapan dan } \\
\text { cita-cita }\end{array}$ & 2,39 & 59,7 & Sedang \\
\hline 4 & $\begin{array}{l}\text { Adanya penghargaan } \\
\text { dalam belajar }\end{array}$ & 2,59 & 64,7 & Tinggi \\
\hline 5 & $\begin{array}{l}\text { Adanya kegiatan } \\
\text { yang menarik dalam } \\
\text { belajar }\end{array}$ & 2,48 & 62,0 & Sedang \\
\hline 6 & $\begin{array}{l}\text { Adanya lingkungan } \\
\text { yang kondusif }\end{array}$ & 2,31 & 57,7 & Sedang \\
\hline 7 & $\begin{array}{l}\text { Ketersediaan dan } \\
\text { kondisi fasilitas }\end{array}$ & 2,36 & 58,9 & Sedang \\
\hline \multirow[t]{2}{*}{8} & $\begin{array}{l}\text { Hambatan yang } \\
\text { dialami saat proses } \\
\text { belajar }\end{array}$ & 2,36 & 59,0 & Sedang \\
\hline & $\begin{array}{c}\text { Rata- } \\
\text { rata }\end{array}$ & 2,46 & 61,1 & Tinggi \\
\hline
\end{tabular}

Berdasarkan Tabel 2 dapat

diketahui rerata mtivasi pada indkator hasrat dan keinginan berhasil 2,57 $(64,13 \%)$ dengan kategori tinggi, 
dorongan dan kebutuhan dalam belajar 2,50 (62,5\%) dengan kategori tinggi, adanya harapan dan cita-cita 2,39 $(59,74 \%)$ dengan kategori sedang, adanya penghargaan dalam belajar 2,59 $(64,74 \%)$ dengan kategori tinggi, adanya kegiatan yang menarik dalam belajar 2,48 $(62,02 \%)$ dengan kategori sedang, adanya lingkungan yang kondusif 2,31 $(58,97 \%)$ dengan kategori sedang, ketersediaan dan kondisi fasilitas 2,36 $(0,59 \%)$, hambatan yang kamu alami saat proses belajar 2,36 (59,01\%). Hal ini membuktikan bahwa kemandirian siswa belajar melalui google classroom termasuk kategori tinggi dan sedang.

Beberapa hal yang menjadi menarik dengan adanya peningkatan baik motivasi maupun hasil belajar adalah guru sudah mampu melaksanakan pembelajaran daring dengan baik (Warmi, et al., 2020). Siswa yang memiliki motivasi belajar tinggi memiliki keinginan untuk memperoleh nilai yang baik sehingga untuk mencapai tujuan tersebut siswa belajar dengan baik dan rajin. Motivasi siswa belajar yang tinggi dapat dilihat berdasarkan indikator salah satunya berkaitan dengan konsentrasi. Menurut Banat dan Martiani (2020) bahwa konsentrasi akan membuat siswa memahami materi yang sedang diajarkan, hal ini didasarkan karena perhatian akan tertuju pada apa yang sedang menjadi daya tarik siswa.

Berdasarkan hasil analisis motivasi belajar siswa pada indikator hasrat dan ingin berhasil dengan skor rata-rata sebesar 2,57 dengan kategori tinggi, hal ini menunjukkan bahwa siswa yang memiliki kemampuan ingin berhasil dalam menyampaikan ide, pendapat dan bersungguh-sungguh mengikuti pelajaran biologi melalui google classroom baik. Menurut Uno (2011) yang mengatakan bahwa hasrat dan keinginan berhasil dalam belajar dan dalam kehidupan seharihari pada umumnya disebut motif berprestasi yaitu motif untuk berhasil dalam melakuakan suatu tugas dan pekerjaan atau motif untuk memperoleh kesempurnaan. Motif semacam ini berasal dari dalam diri manusia yang bersangkutan karena merupakan unsur kepribadian dan prilaku manusia itu sendiri.

Berdasarkan hasil analisis motivasi belajar siswa pada indikator dorongan dan kebutuhan belajar siswa dengan skor rata-rata sebesar 2,50 dengan kategori tinggi, hal ini menunjukkan bahwa siswa memiliki antusias dan dorongan yang sangat kuat untuk mendapatkan nilai terbaik dari setiap tugas yang diberikan setelah proses pembelajaran. Keinginan untuk mendapatkan nilai terbaik harus didorong dengan usaha dan kerja keras yang tinggi baik dalam proses kegiatan pembelajaran maupun pada dari saat mengerjakan tugas pembelajaran (Fitriyani, et al., 2020).

Berdasarkan hasil analisis motivasi belajar siswa pada indikator adanya harapan dan cita-cita dengan skor rata-rata sebesar 2,39 dengan kategori sedang, hal ini menunjukkan bahwa siswa kurang bersemangat belajar. Motivasi dan semangat belajar mempunyai hubungan yang sangat penting pada kegiatan pembelajaran, ini menunjukkan bahwa baik guru dan siswa harus menunjukkan semangat yang tinggi pada setiap kegiatan pembelajaran. Menurut Sadirman (2014) harapan dan cita-cita seorang siswa merupakan alat motivasi yang sangat penting sebab dengan memahami harapan dan cita-cita yang harius dicapai sangat berguna dan menguntungkan, maka akan timbul keinginan siswa untuk terus belajar agar tercapai cita-cita masa depan yang di inginkannya.

Berdasarkan hasil analisis motivasi belajar siswa pada indikator adanya penghargaan dalam belajar dengan skor rata-rata sebesar 2,59 dengan kategori tinggi, hal ini menunjukkan bahwa pujian yang diberikan oleh guru membuat siswa lebih bersemangat untuk mengikuti proses bembembelajaran. Menurut Sadirman (2014) mengatakan bahwa bila ada siswa yang sukses dan berhasil menyelesaikan tugas dengan baik, perlu diberikan pujian, pujian ini adalah bentuk reinforcement yang positif sekaligus merupakan motivasi yang baik. Oleh karena itu, dengan memberikan pujian yang tepat akan membuat suasana belajar yang menyenangkan dan menambah gairah belajar sekaligus akan membangkitkan semangat siswa.

Berdasarkan hasil analisis motivasi belajar siswa pada indikator adanya kegiatan yang menarik dalam belajar dengan skor rata-rata sebesar 2,48 dengan kategori sedang, hal ini menunjukkan bahwa siswa jarang aktif 
saat belajar dan membuat siswa malas belajar karena tidak bisa praktek langsung kelapangan. Depdikbud (2002) menyatakan bahwa pembelajaran yang menarika adalah pembelajaran yang menyenangkan, menggirangkan hati dan mempengaruhi atau membangkitkan hasrat untuk memperhatikan.

Berdasarkan hasil motivasi belajar siswa pada indikator adanya lingkungan yang kondusif dengan skor rata-rata 2,31 dengan kategori sedang, hal ini menunjukkan bahwa siswa kurang setuju ketika diberikan tugas mendadak dan siswa tidak berani bertanya jika pelajaran sulit dipamhami oleh siswa, hal itu disebabkan karena keadaan group kelas yang kurang aktif. Menurut Slameto (2013) suasana rumah yang gaduh atau ramai tidak akan memberikan ketenangan pada anak dalam belajar, suasana rumah yang tenang dan tentram sangat perlu diciptakan agar anak dapat belajar dengan baik.

Berdasarkan hasil motivasi belajar siswa pada indikator ketersediaan dan kondisi fasilitas dengan skor rata-rata 2,36 dengan kategori sedang, hal ini menunjukkan bahwa jaringan internet yang digunakan tidak stabil sehingga membuat siswa selalu terlambat masuk di google calassroom dan siswa mengerjakan tugas apabila jaringannya stabil. Menurut Kurniawan \& Wustqa (2014) melalui motivasi belajar diharapkan lebih giat dalam belajarnya. Harapannya meskipun pembelajaran dilakukan secara daring tetapi motivasi dapat terus ditingkatkan melalui interaksi dunia maya yang dilakukan oleh guru biologi.

Berdasarkan hasil motivasi belajar siswa pada indikator hambatan yang dialami saat proses belajar dengan skor rata-rata 2,36 dengan kategori sedang, hal ini menunjukkan bahwa siwa kurangnya konsentrasi saat belajar dan siswa lebih memilih main games dari pada belajar. Menurut Lestari, et al. (2018) motivasi perlu dikembangkan oleh siswa dalam belajar.

Berdasarkan rata-rata skor angket motivasi belajar siswa diketahui bahwa indikator yang memperoleh skor tertinggi yaitu indikator 4 tentang adanya penghargaan dalam belajar, dengan skor 2,59 termasuk dalam kategori tinggi. Hal ini berarti ketika siswa mengikuti pembelajaran biologi melalui google classroom, mereka semakin termotivasi dalam menumbuhkan semangat belajar siswa dengan penghargaan yang diberikan guru pada saat pembelajaran biologi berlangsung pada google classroom. Contohnya, ketika guru memberikan tugas, guru akan memberikan reward atau hadiah yang paling cepat mengumpulkan tugas akan diberikan nilai yang tinggi. Tingkat terendah pada angket motivasi belajar siswa melaui google classroom pada indikator 6 tentang lingkungan belajar yang kondusif, dengan skor 2,31 tetapi masih termasuk dalam kategori sedang. Hal ini menunjukkan bahwa siswa kurang berinteraksi antara siswa dengan lingkungan, sehingga terjadi kurangnya pengetahuan dan keterampilan belajar siswa. Contohnya ketika pada saat belajar digoogle classroom siswa kurang merespon atau tidak aktif saat pembelajaran berlangsung, sehingga materi yang disampaikan oleh guru banyak yang siswa yang tidak mengerti, sehingga pada saat ujian banyak siswa yang mendapatkan nilai yang rendah.

\section{KESIMPULAN}

Berdasarkan hasil penelitian dan analisis data dapat disimpulkan bahwa kemandirian dan motivasi belajar siswa melalui google classroom pada masa pandemi covid-19 pada kelas XII IPA SMAN 1 Rokan IV Koto memiliki kategori sedang, yaitu kemandirian dengan skor rata-rata 2,19 termasuk kategori Sedang dan motivasi belajar yaitu menunjukkan skor rata-rata 2,46 dengan termasuk kategori tinggi.

\section{DAFTAR PUSTAKA}

Banat, A \& Martiani. (2020). Kemandirian Belajar Mahasiswa Penjas Menggunakan Media Google classroom melalaui hybrid learning pada pembelajaran profesi pendidikan dimada pandemicovid -19 . Jurnal teknologi pendidikan, 13(2).

Bungsu, T. K., Vilardi, M., Akbar, P., \& Bernard, M. (2019). Pengaruh Kemandirian Belajar Terhadap Hasil Belajar Matematika di SMKN 1 Cihampelas. Jurnal 
Sosial Humaniora, 1(2), 382389.

Cleopatra, M. (2015). Pengaruh Gaya Hidup dan Motivasi Belajar terhadap Prestasi Belajar Matematika. Formatif: Jurnal Ilmiah Pendidikan MIPA, 5(2), 168-181

Egok, A. S. (2016). Kemampuan Berpikir Kritis Dan Kemandirian Belajar Dengan Hasil Belajar Matematika. Jurnal Pendidikan Dasar, 7(2), 186.

Fajriah, L., Nugraha, Y., Akbar, P., \& Bernard, M. (2019). Pengaruh Kemandirian Belajar Siswa SMP Terhadap Kemampuan Penalaran Matematis. Journal on Education, 1(2), 288-296

Firman, F., \& Rahayu, S. (2020). Pembelajaran Online di Tengah Pandemi Covid-19. Indonesian Journal of Educational Science (IJES), 2(2), 81-89.

Fitriyani Y., Fauzi I., \&Sari M.Z, 2020. Motivasi Belajar Mahasiswa Pada Pembelajaran Daring Selama Pandemik Covid-19. Jurnal Hasil Penelitian dan Kajian Kepustakaan di Bidang Pendidikan, Pengajaran dan Pembelajaran. 2 (6)

Hamalik, O. 2010. Kurikulum dan Pembelajaran. Bumi Aksara. Jakarta

Jumaisyaroh, T., Napitupulu, E. E., \& Hasratuddin, H. (2015). Peningkatan Kemampuan Berpikir Kritis Matematis Dan Kemandirian Belajar Siswa Smp Melalui Pembelajaran Berbasis Masalah. Kreano, Jurnal Matematika Kreatif-Inovatif, 5(2), 157

Khasanah, D. R. A. U., Pramudibyanto, H., \& Widuroyekti, B. (2020). Pendidikan Dalam Masa Pandemi Covid-19. Jurnal Sinestesia, 10(1), 41-48.

Kurniawan, D., \& Wustqa, D. U. (2014). Pengaruh Perhatian Orangtua,
Motivasi Belajar, Dan Lingkungan Sosial Terhadap Prestasi Belajar Matematika Siswa Smp. Jurnal Riset Pendidikan Matematika, 1(2), 176

Lestari, W. (2017). Pengaruh Kemampuan Awal Matematika dan Motivasi Belajar terhadap Hasil Belajar Matematika. Jurnal Analisa, 3(1), 76

Lestari, Wahyu, Pratama, L. D., \& Jailani, J. (2018). Implementasi Pendekatan Saintifik Setting Kooperatif Tipe STAD Terhadap Motivasi Belajar Dan Prestasi Belajar Matematika. AKSIOMA : Jurnal Matematika Dan Pendidikan Matematika. 9(1), 29.

Lomu, L., \& Widodo, S. A. (2018). Pengaruh Motivasi Belajar Dan Disiplin Belajar Terhadap Prestasi Belajar Matematika Siswa. Prosiding Seminar Nasional Pendidikan Matematika Etnomatnesia, 0(0), 745-751.

Kartadinata, S. (2001). Kemandirian belajar dan orientasi nilai mahasiswa. Bandung: PPS.

Masruroh, R. D., Karyanto, P., \& Indrowati, M. (2014). Studi Komparasi Pemahaman Konsep Sistem Pernapasan Manusia Melalui Penerapan Pembelajaran Konstruktivisme tipe Novick Dipadu Concept Map dan Ceramah Bervariasi. BIOEDUKASI Jurnal Pendidikan Biologi Volume 7, Nomor 1.

Murti, E. D., Nasir, N., \& Negara, H. S. (2019). Analisis Kemampuan Pemecahan Masalah Matematis : Dampak Model Pembelajaran SAVI ditinjau dari Kemandirian Belajar Matematis. Desimal: Jurnal Matematika, 2(2), 119129.

Ningsih, R., \& Nurrahmah, A. (2016). Pengaruh Kemandirian Belajar dan Perhatian Orang Tua Terhadap Prestasi Belajar Matematika. Formatif: Jurnal Ilmiah Pendidikan MIPA, 6(1), 73-84 
Purwanto, A., Pramono, R., Asbari, M., Santoso, P. B., Wijayanti, L. M., Choi, C. H., \& Putri, R. S. (2020). Studi Eksploratif Dampak Pandemi COVID-19 Terhadap Proses Pembelajaran Online di Sekolah Dasar. EduPsyCouns: Journal of Education, Psychology and Counseling, 2(1), 1-12.

Pujilestari, Y. (2020). Dampak Positif Pembelajaran Online Dalam Sistem Pendidikan Indonesia Pasca Pandemi Covid 19. Adalah: Buletin Hukum Dan Keadilan, 4(1), 49-56

Sardiman. (2014). Interaksi dan Motivasi Belajar Mengajar. Jakarta: Rajawali.

Slameto. (2003). Belajar dan Faktorfaktor yang Mempengaruhinya. Jakarta: PT Rineka Cipta

Suhendri, H. (2015). Pengaruh Metode Pembelajaran Problem Solving terhadap Hasil Belajar Matematika Ditinjau dari Kemandirian Belajar. Formatif: Jurnal Ilmiah Pendidikan MIPA, 3(2), 105-114.
Susilowati D. (2009). Upaya meningkatkan kemandirian belajar dan kemampuan matematika siswa kelas X SMA N 1 Gamping dengan menggunakan lembar kerja siswa. Jurnal swabumi. 7(1).

Tahar, I. (2006). Hubungan Kemandirian Belajar dan Hasil Belajar Pendidikan Jarak Jauh. (online)

.(http//:jurnalpendidikanterbukad an jarakjauh.html, diakses 9 Juni (2021) 2(3).

Warmi A, Adirakasiwi A.G., \& Santoso E. (2020). Motivasi Dan Kemandirian Belajar Siswa Pada Mata Pelajaran Matematika Di Masa Pandemi Covid-19 (Studi Pada Siswa Kelas Vii Smpn 3 Karawang Tahun Pelajaran 20192020). Jurnal Education and development Institut Pendidikan Tapanuli Selatan.3(8).

Uno, B, Hamzah. (2015). Teori Motivasi dan Pengukuran. Gorontalo: Bumi Aksara. 